\title{
TORAJYVÄSIENEN, CLAVICEPS PURPUREA (FR.) TUL:n, LEVIÄMISESTÄ JA TORJUNNASTA
}

\author{
AnNa-LiIsA RuOKola \\ Helsingin yliopiston kasvipatologian laitos, Viikin koetila
}

Saapunut 12. 2. 1957

Torajyvän viljelyyn, jota viime aikoina on Suomessakin tutkittu $(1,19)$ ja ryhdytty jo käytännössäkin harjoittamaan (1), liittyy läheisesti kysymys sienen leviämisestä rukiin talousviljelmiin. Kysymykseen on kiinnitetty huomiota, koska torajyvä on ihmisille ja eläimille hyvin myrkyllinen (vrt. 2, 3, 7, 20, 21, 25). Sen vuoksi, että saastutetun rukiin välittömässä läheisyydessä kasvavien tähkien saastunnan vaara on varsin suuri, suositellaan kirjallisuudessa muutaman metrin $(10,17)$ tai muutaman sadan metrin (11) levyistä suojavyöhykettä erottamaan saastutettu alue rukiin talousviljelmästä. Sitä paitsi suositellaan maahan varisseiden torajyvien hautaamista syväkynnöllä $(3,4,16,17,24)$. Myös viljan lajittelun merkitys on jo kauan oivallettu $(3,20,24)$.

Saksassa pidetään $0.1 \%$ :n torajyvämäärää kauppaviljassa sallittuna maksimina (vrt. 8), mikä soveltunee meidänkin oloihimme, kun on kysymyksessä viljeltävät, runsasalkaloidiset torajyväkannat. Suomessa nykyisin voimassa olevaa kauppakelpoisuusvaatimusta $(0.25 \%)$ lienee sen sijaan tässä tapauksessa pidettävä liian lievänä (vrt. 23). Viljasta vaikeimmin erotettavia ovat rukiin jyvän kokoiset torajyvät (20). Helsingin yliopiston Viikin koetilalla vuosina 1952--1955 suoritetuissa tutkimuksissa on erityistä huomiota kiinnitetty torajyväsienen leviämiseen, saastuneen rukiin jyväsadon määrään ja laatuun sekä mahdollisuuteen puhdistaa saastunut ruissato viljan lajittelulla.

\section{Tutkimusolosuhteet, -aineisto ja -menetelmät}

Sääsuhteet olivat Helsingissä vuosina 1952-1955 torajyväsienen leviämiselle yleensä verraten suotuisat (vrt. 14). Kesäkuun viimeisten viikkojen aikana, jolloin sienen leviäminen pääasiallisesti tapahtui, sää oli lämpimin ja runsassateisin v. 1953, kylmin ja vähäsateisin v. 1955 .

Tutkimuksiin otettiin mukaan kotimaiset syysruislajikkeet Ensi, Oiva ja Pekka sekä saksalainen Petkus-kevätruis. V. 1952 syysrukiin lajikekokeeseen kuuluvat Oiva- ja Pekka-ruis saastutettiin $45 \mathrm{~cm}$ :n leveydeltä koeruudun $(6.67 \times 3.00)$ reunasta lukien, keskiosan (210 cm:n leveydeltä) jäädessä käsittelemättä. Rukiin tuleentumisaikana tai vaihtoehtoisesti n. 10 p. sitä ennen torajyvät laskettiin koe- 
ruudun saastutetuilta reunoilta ja $0-11 \mathrm{p}$. ennen rukiin tuleentumista koeruudun saastuttamattomasta keskiosasta. Muina vuosina saastutettiin koeruudut kokonaisuudessaan (vrt. 19).

Torajyväsienen leviämistä kauemmaksi tutkittiin Ensi-rukiin talousviljelmissä vuosina 1952 - 1954. Saastutetut kasvustot erotettiin 1.0-1.5 m:n levyisellä käytävällä rukiin talousviljelmästä, joten välitöntä kosketustartuntaa tuskin pääsi tapahtumaan; vain v. 1952 välikäytävä puuttui. Suoraviivaisia linjoja seuraten torajyvät laskettiin erikseen perättäisiltä $2-3 \mathrm{~m}$ :n levyisiltä ja $10-20 \mathrm{~m}$ :n pituisilta erisuuntaisilta kaistoilta. Kun saastunnan leviämisessä eri suuntiin ei kuitenkaan ilmennyt johdonmukaisia eroja, tyydytään tulokset esittämään kunkin viljelmän eri linjoilta (5-8 linjaa) todettujen torajyvälukujen keskiarvoina (taulukko 1). Torajyvät laskettiin saastutetuilta aloilta joko rukiin tuleentumisaikana tai vaihtoehtoisesti $2-12$ p. sitä ennen sekä saastuttamattomilta aloilta $15-23$ p. (v. 1952) ja $1-10$ p. (vuosina 1953-1954) ennen rukiin tuleentumista.

Lajittelun kannalta tärkeän torajyvien ominaispainon määrittäminen suoritettiin upottamalla torajyvät veteen mittalasissa (n. $20^{\circ} \mathrm{C}$ ), jolloin mittalasin asteikosta voitiin suoraan lukea torajyvien tilavuus $\mathrm{cm}^{3}$ :nä. Vastaavaa grammamääräistä painoa jaettuna tilavuusluvulla pidettiin ominaispainona. Rukiin jyvien ominaispaino määritettiin samalla tavoin. Torajyvien ja rukiin jyvien erotteleminen eri suuruusluokkiin tapahtui tiheydeltään erilaisilla seuloilla.

Tulosten luotettavuutta tarkastettiin tilastomatemaattisesti BonNiER ja Tedinin (6) mukaisesti suoritetulla varianssianalyysilla. Koetulosten keskiarvon keskivirheen laskemiseen käytettiin kaavaa $\mathrm{m}=\sqrt{\frac{\mathrm{S}(\mathrm{X}-\overline{\mathrm{X}})^{2}}{\mathrm{n}(\mathrm{n}-1)}}$, jossa $\mathrm{X}=$ muuttuja, $\bar{X}=$ muuttujien keskiarvo ja $\mathrm{n}=$ muuttujien lukumäärä.

Taulukko 1. Torajyväsienen leviäminen Ensi-rukiin talousviljelmissä vuosina 1952 - 1954 .

Tabelle 1. Das Ausbreiten des Mutterkornpilzes auf den Roggen Ensi in Wirtschaftskulturen in d. J. $1952-1954$.

\begin{tabular}{|c|c|c|c|c|c|c|c|c|c|}
\hline \multirow{4}{*}{$\begin{array}{c}\text { Etäisyys } \\
\text { saastutetusta } \\
\text { alasta }(\mathrm{m}) \\
\text { Abstand von } \\
\text { der infizierten } \\
\text { Fläche }(\mathrm{m})\end{array}$} & \multicolumn{9}{|c|}{ Torajyviä keskim. $\mathrm{kpl} / 100 \mathrm{~m}^{2}-$ Mutterkörner durchschn. St./100 $\mathrm{m}^{2}$} \\
\hline & \multirow{2}{*}{\multicolumn{2}{|c|}{1952}} & \multicolumn{4}{|c|}{1953} & \multirow{2}{*}{\multicolumn{3}{|c|}{1954}} \\
\hline & & & & $\begin{array}{l}\text { elmä } 1 \\
\text { ultur } 1\end{array}$ & & $\begin{array}{l}\text { Imä } 2 \\
\text { tur } 2\end{array}$ & & & \\
\hline & 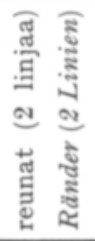 & 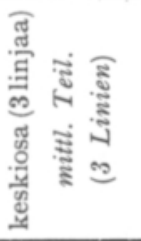 & 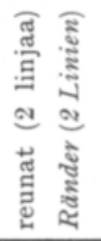 & 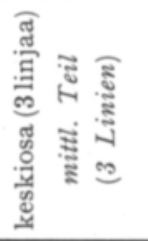 & 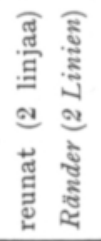 & 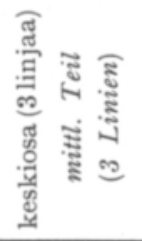 & 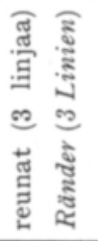 & 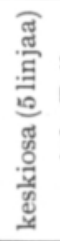 & 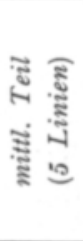 \\
\hline $0-10$ & 3 & 32 & 608 & 494 & 802 & 456 & 176 & & 355 \\
\hline $10-30$ & 1 & 5 & 396 & 96 & 503 & 99 & 161 & & 63 \\
\hline $30-50$ & 0 & 4 & 382 & - & 155 & 33 & 95 & & 18 \\
\hline $50-70$ & 0 & 1 & - & - & 173 & 27 & 142 & & - \\
\hline $70-90$ & 0 & 0 & - & - & 135 & 67 & 164 & & - \\
\hline $90-100$ & - & - & - & - & 479 & 20 & - & & - \\
\hline
\end{tabular}


Torajyväsienen välittömän leviämisen saastuneesta rukiista terveeseen aiheuttaa sienen kuroma-aste, Sphacelia segetum Lev. (12). Saastunta tapahtuu tähkien koskettaessa toisiaan ja hyönteisten imiessä mesikastetta. Eräissä Itävallassa suoritetuissa tutkimuksissa hyönteisten osuus oli n. $10 \%(10)$. Rukiin kasvuston ollessa tasaista, jolloin ruisviljelmän kukinta-aika on suhteellisen lyhyt, hyönteisten merkitystä pidetään kuitenkin verraten vähäisenä (vrt. 15). Viikin koetilalla suoritettujen rukiin saastutuskokeiden mesikasteisissa tähkissä vierailevista hyönteislajeista yleisimpiä olivat erilaiset kärpäset; v. 1954 esiintyi sitä paitsi varsin runsaslukuisena tummaa sylkikuoriaista (Cantharis obscura L.).

Saastutettujen kasvien välittömästi koskettaessa niitä ympäröiviä kasveja torajyväsaastunta oli suhteellisen suuri. Niinpä v. 1952 saastutettujen koeruutujen saastuttamattomilta aloilta, ruutujen keskiosista, poimittujen torajyvien lukumäärä oli Oiva-rukiissa keskimäärin $29 \mathrm{kpl} / \mathrm{m}^{2}$ ja Pekka-rukiissa $42 \mathrm{kpl} / \mathrm{m}^{2}$ eli 3.6 ja $5.0 \%$ vastaavilta saastutetuilta aloilta lasketuista torajyväluvuista.

Sienen leviämisestä Ensi-rukiin talousviljelmissä (viljelmien reunoja lukuun ottamatta) suoritetut tutkimukset osoittivat, että $1-10 \mathrm{~m}: \mathrm{n}$ etäisyydellä saastutetusta alasta oli torajyviä $0.4 \%$ vastaavan saastutetun alan torajyväluvusta eli keskimäärin 334 torajyvää aaria kohden (taulukko 1); $10-30 \mathrm{~m}$ :n etäisyydeltä torajyviä löytyi vielä vähemmän, keskimäärin $66 \mathrm{kpl}$ aaria kohden. Yleensä saastuneisuus heikkeni, kun välimatka saastutetuista aloista kasvoi, joskin paikoitellen torajyviä oli suhteellisen paljon verraten kaukanakin saastutetusta alasta, erityisesti siellä, missä ruiskasvusto oli aukkoista. Onkin todettu, että rukiin kasvuston ollessa harvaa kehittyy myöhäisversoja, jotka puutteellisen hedelmöityksen vuoksi saastuvat herkästi (13). Sitä paitsi ruisviljelmien reunakasvustoissa, ilmeisesti samasta syystä (vrt. 9,11), torajyviä esiintyy tavallista enemmän. Tähän lienee osittain vaikutusta myös hyönteisten runsaalla esiintymisellä pellon reunaosissa (vrt. 4,22). Eräiden Itävallassa suoritettujen tutkimusten mukaan hyönteiset kuljettivat sienen kuromia jopa 1 kilometrin päähän saastuneista tähkistä (10). Myös Viikin koetilalla tutkittiin torajyvän leviämistä ruisviljelmän reunaosiin. Näiden tutkimusten perusteella (taulukko 1) näyttää siltä, että torajyväsaastunta on, varsinkin suhteellisen kaukana saastutetusta rukiista, ollut runsaampaa viljelmän reuna- kuin keskiosissa. Tämä tulos viittaa siihen, että hyönteisillä on ollut huomattava merkitys torajyväsienen kaukoleviämisessä.

Torajyvien luku saastunutta $\mathrm{t}$ ä h k ä ä k o h d e n oli suurempi saastutetuilla $(4.9-5.9 \mathrm{kpl}) \mathrm{kuin}$ vastaavilla saastuttamattomilla (vrt. taulukko 2) koealoilla. Tämä luku ei sen sijaan näyttänyt olleen riippuvainen siitä, kuinka kaukana kasvi oli saastutetusta rukiista. Kuitenkin torajyviä oli tähkää kohden keskimäärin vähän enemmän ruisviljelmän reuna- kuin keskiosissa, mikä tukee edellä esitettyä käsitystä, että hyönteisillä on ollut osuutta torajyväsienen leviämisessä ruisviljelmien reunaosiin. Käytännössä voitaneen torajyväviljelmän läheisyydessä sijaitsevan ruisviljelmän sadon torajyväpitoisuutta vähentää niittämällä reunaosat ennen varsinaista sadon korjuuta. 
Taulukko 2. Torajyvien luku saastunutta tähkää kohden Ensi-rukiin talousviljelmissä vv. 1953 - 1954.

Tabelle 2. Die Anzahl der Mutterkörner je infizierte Ahre in den Wirtschaftskulturen des Roggens Ensi in d. J. $1953-1954$.

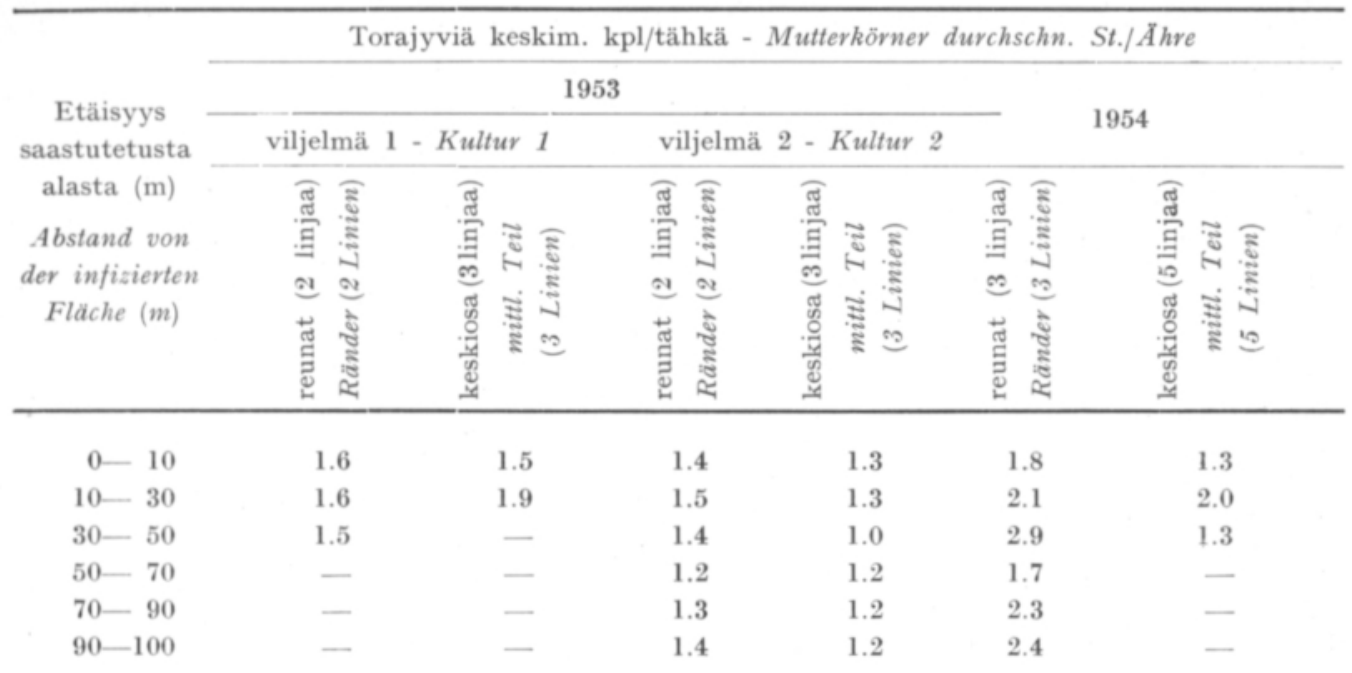

Taulukko 3. Torajyväsienellä saastutetun rukiin seulalajittelun tulokset vuosina $1952-1955$.

Tabelle 3. Die Ergebnisse des Siebsortierens bei dem mit dem Mutterkornpilz infizierten Roggen in d. J. 1952-1955.

\begin{tabular}{|c|c|c|c|c|c|c|c|}
\hline \multirow[b]{2}{*}{$\begin{array}{l}\text { Vuosi } \\
\text { Jahr }\end{array}$} & \multirow[b]{2}{*}{$\begin{array}{c}\text { Ruis } \\
\text { Roggen }\end{array}$} & \multicolumn{3}{|c|}{$\begin{array}{c}\text { Jyviä }(\%) \text { eri lajitteissa } \\
\text { Körner }(\%) \text { in den versch. Fraktionen }\end{array}$} & \multicolumn{2}{|c|}{$\begin{array}{l}1000 \text { jyvän paino } \\
1000 \text {-Korngewicht }\end{array}$} & \multirow{2}{*}{$\begin{array}{l}\text { Ominais- } \\
\text { paino } \\
\text { Spez. } \\
\text { Gewicht }\end{array}$} \\
\hline & & $\begin{array}{l}<2,1 \times 6.5 \\
\mathrm{~mm}\end{array}$ & $\begin{array}{l}2.1 \times 6.5 \\
\mathrm{~mm}\end{array}$ & $\begin{array}{l}2.5 \times 7.5 \\
\mathrm{~mm}\end{array}$ & g & $\begin{array}{c}\text { Suhdeluku } \\
\text { Verhält- } \\
\text { niszahl }\end{array}$ & \\
\hline \multirow[t]{3}{*}{1952} & $\begin{array}{l}\text { Saastutettu } \\
\text { Infiziert }\end{array}$ & & & & & & \\
\hline & $\begin{array}{l}\text { Terveet tähkät } \\
\text { Gesunde Ahren }\end{array}$ & 19.9 & 59.5 & 20.6 & 25.0 & 100 & 1.17 \\
\hline & $\begin{array}{l}\text { Saastuneet tähkät } \\
\text { Befallene Ahren }\end{array}$ & 35.5 & 52.7 & 11.8 & 20.6 & 82 & 1.17 \\
\hline \multirow[t]{2}{*}{1953} & $\begin{array}{l}\text { Saastuttamaton } \\
\text { Nichtinfiziert }\end{array}$ & 33.9 & 42.8 & 23.3 & 24.3 & 100 & 1.15 \\
\hline & $\begin{array}{l}\text { Saastutettu } \\
\text { Infiziert }\end{array}$ & 61.0 & 34.8 & 4.2 & 17.3 & 71 & 1.22 \\
\hline \multirow[t]{2}{*}{1954} & $\begin{array}{l}\text { Saastuttamaton } \\
\text { Nichtinfiziert }\end{array}$ & 44.1 & 52.0 & 3.9 & 18.9 & 100 & 1.15 \\
\hline & $\begin{array}{l}\text { Saastutettu } \\
\text { Infiziert }\end{array}$ & 82.7 & 16.7 & 0.6 & 11.9 & 63 & 1.10 \\
\hline \multirow[t]{2}{*}{1955} & $\begin{array}{l}\text { Saastuttamaton } \\
\text { Nichtinfiziert }\end{array}$ & 49.4 & 43.0 & 7.6 & 20.2 & 100 & 1.07 \\
\hline & $\begin{array}{l}\text { Saastutettu } \\
\text { Infiziert }\end{array}$ & 56.6 & 36.1 & 7.3 & 18.7 & 93. & 1.11 \\
\hline
\end{tabular}


Viikin koetilalla olivat Ensi-rukiin saastutettujen alojen keskimääräiset jyväsadot vuosina 1953-1955 23-77\% (taulukko 5) saastuttamattomien alojen jyväsadoista. Torajyvän viljasatoa vähentävä vaikutus johtuu rukiin jyväluvun pienentymisestä ja jyvien jäämisestä normaalia pienikokoisemmiksi. KiRCHHOFFin (12) kokoamien tietojen mukaan jyväluvun pienentymisestä johtuvat tappiot saattavat kohota jopa kolmannekseen jyvien kokonaisluvusta. Hänen omissa tutkimuksissaan on vastaava satotappio kuitenkin ollut paljon vähäisempi, vain $0.47-1.30 \%$ sadon määrästä, siitä huolimatta että tutkittu ruis oli saastutettu keinotekoisesti. Saastuneiden tähkien normaalia kevyemmiksi jääneistä jyvistä aiheutunut satotappio osoittautui KIRCHHOFFin (12) näissä kokeissa suuremmaksi, 3.2-8.3\%:ksi. Viikin koetilan kokeissa vastaava ero oli v. 1952 vielä suurempi, keskimäärin $17.6 \%$ (taulukko 3). Tutkimuksiin käytettiin tällöin Ensi-, Oiva-, Pekka- ja Petkusruista. Vuosina 1953-1955 suoritettiin Viikissä vertailu koetilan talousviljelmän saastutetun ja saastuttamattoman Ensi-rukiin 1000 jyvän painojen välillä. Saastutettujen alojen satoon sisältyivät siis sekä sairaiden että terveiksi jääneiden tähkien jyvät. Tästä huolimatta jyvät olivat $7.4-37.0 \%$ saastuttamattomilla aloilla kasvaneen rukiin jyviä kevyempiä (taulukko 3). Ruis korjattiin kaikkina koevuosina täysin tuleentuneena. Rukiin jyvän suurentumista torajyvän korjuun ja rukiin leikkuun välisenä aikana ei ollut varmuudella todettavissa.

Viikin koetilan kokeissa johtuivat rukiin suhteellisen alhaiset jyväsadot paitsi torajyväsienen aiheuttamasta rukiin jyvän pienentymisestä (taulukko 3) sekä

Taulukko 4. V. 1952 saastutetun rukiin orastuminen tammikuussa v. 1953. Orastumisnopeus määritetty 9 p:n (orastumisajan alkupuoliskon) kuluttua kokeen alkamisesta. Jyvät poimittu tähkistä käsin.

Tabelle 4. Das Aufspriessen des im J. 1952 infizierten Roggens im Januar 1953. Die Geschwindigkeit des Aufspriessens $9 \mathrm{Tg}$ (die erste Hälfte der Zeit des Aufspriessens) nach Versuchsbeginn bestimmt. Die Körner mit der Hand aus den Ahren gepflückt.

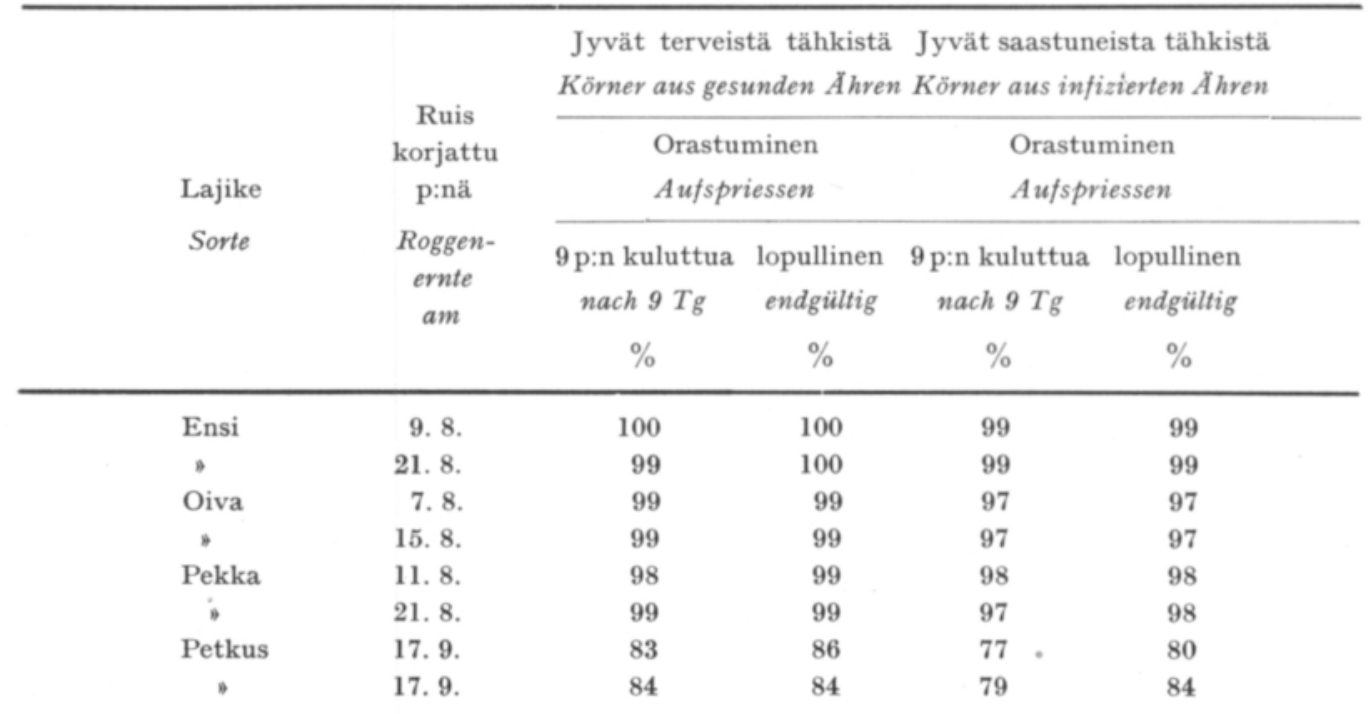


Taulukko 5. Vuosina 1953-1955 saastutetun Ensi-rukiin jyväsadon orastuminen. (Orastumiskokeet suoritettu tammi-helmikuussa).

Tabelle 5. Das Aufspriessen beim Kornertrag des in den Jahren 1953-1955 infizierten Roggens Ensi (Aufspriessversuche Januar-Februar ausgeführt).

\begin{tabular}{|c|c|c|c|c|c|}
\hline \multirow[b]{2}{*}{$\begin{array}{l}\text { Vuosi } \\
\text { Jahr }\end{array}$} & \multirow[b]{2}{*}{$\begin{array}{c}\text { Ruis } \\
\text { Roggen }\end{array}$} & \multirow{2}{*}{$\begin{array}{l}\text { Suhteellinen } \\
\text { jyväsato } \\
\text { Relativer } \\
\text { Kornertrag }\end{array}$} & \multicolumn{2}{|c|}{$\begin{array}{l}\text { Orastuminen } \\
\text { Aufspriessen }\end{array}$} & \multirow{2}{*}{$\begin{array}{l}\text { Sienien tuhoamia } \\
\text { oraita orastumi- } \\
\text { sen jälkeen } \\
\text { Pilzvernichtete } \\
\text { Saat nach dem } \\
\text { Aufspriessen }\end{array}$} \\
\hline & & & $\begin{array}{c}9 \text { p:n kuluttua } \\
\text { nach } 9 T g \\
\%\end{array}$ & $\begin{array}{l}\text { lopullinen } \\
\text { endgültig } \\
\%\end{array}$ & \\
\hline \multirow[t]{2}{*}{1953} & $\begin{array}{l}\text { Saastuttamaton } \\
\text { Nichtinfiziert }\end{array}$ & 100 & $91 \pm 1.73$ & $91 \pm 1.73$ & $4.0 \pm 1.15$ \\
\hline & $\begin{array}{l}\text { Saastutettu } \\
\text { Infiziert }\end{array}$ & 66 & $58 \pm 1.29$ & $62 \pm 1.43$ & $10.0 \pm 0.96$ \\
\hline \multirow[t]{2}{*}{1954} & $\begin{array}{l}\text { Saastuttamaton } \\
\text { Nichtinfiziert }\end{array}$ & 100 & $96 \pm 0.91$ & $97 \pm 1.00$ & $4.0 \pm 1.00$ \\
\hline & $\begin{array}{l}\text { Saastutettu } \\
\text { Infiziert }\end{array}$ & 23 & $97 \pm 0.66$ & $97 \pm 0.49$ & $5.0 \pm 0.57$ \\
\hline \multirow[t]{2}{*}{1955} & $\begin{array}{l}\text { Saastuttamaton } \\
\text { Nichtinfiziert }\end{array}$ & 100 & $82 \pm 1.03$ & $85 \pm 0.94$ & $0.8 \pm 0.26$ \\
\hline & $\begin{array}{l}\text { Saastutettu } \\
\text { Infiziert }\end{array}$ & 77 & $93 \pm 0.54$ & $95 \pm 0.51$ & $0.6 \pm 0.14$ \\
\hline
\end{tabular}

jyväluvun alenemisesta, myös siitä, että saastutuksen yhteydessä tapahtui tähkien ja korsien vioittumista; tässä tapauksessa saastutus suoritettiin käsivaraisesti (vrt. 19). Myös koneellisessa infektiossa tapahtunee rukiin korsien vioittumista (5).

Saastutetun rukiin jyväsato aleni v. 1954 kaikkein eniten. Silloin torajyväsienen saastuttamissa tähkissä esiintyi erittäin runsaasti viljan mustahärmäsientä, Cladosporium herbarum (Pers.) Link, kuitenkin vain saastutuksen yhteydessä vioittuneissa tähkissä.

Torajyväsienellä saastutetun rukiin laatua kuvastaa lisäksi jyväsadon orastuvuus. V:n 1952 orastumiskokeissa saastuneiden tähkien jyvät orastuivat vain vähän heikommin kuin terveiden tähkien jyvät (taulukko 4); v:n 1953 kokeessa ne orastuivat selvästi heikommin, mutta vuosina 1954 ja 1955 saastutetun rukiin jyväsato orastui vähintään yhtä hyvin kuin saastuttamattoman. Torajyväsienen eri kantojen vaikutusten välillä ei tässä suhteessa ollut varmuudella todettavia eroja. V:n 1953 sadosta tavattujen kuolleiden oraiden suuri määrä johtui pääasiallisesti Fusarium-suvun sienten aiheuttamista tuhoista (taulukko 5).

Rukiin korjuuaika ei näissä kokeissa yleensä vaikuttanut jyväsadon orastuvuuteen. Petkus-kevätrukiin jyväsadon heikkoon orastumiseen (taulukko 4) lienee kuitenkin syynä sen tuleentumisajan siirtyminen kovin myöhäiseen syksyyn.

\section{Lajittelun vaikutus}

Miten täydellisesti torajyvät ovat lajittelussa erotettavissa ruissadosta, riippuu ensisijaisesti rukiin jyvien ja torajyväsienen sklerotioiden koosta ja ominaispainosta. 
Keskimäärin oli torajyväsienen sklerotioiden ominaispaino 1.06 (1.00-1.14), Ensirukiin 1.15 (taulukko 3). Ensi-rukiin 1000 jyvän paino oli 11.9 - 24.4 g (taulukko 3), torajyväsienen sklerotioiden keskimäärin $46.7 \mathrm{~g}$ (taulukko 6). Kuitenkin torajyvien koko vaihteli hyvin suuresti; suurimpien torajyvien 1000 jyvän paino oli paljon yli $100 \mathrm{~g}$, pienimmät olivat puolestaan samaa suuruusluokkaa kuin pienet rukiin jyvät (taulukko 3). Jyvän koon perusteella torajyviä ei siis täydellisesti voida poistaa viljasta. Ominaispainoerokin on niin pieni, että senkin perusteella lajitteleminen tuottanee vaikeuksia. Kuitenkin juuri ominaispainoeroon on perustunut aikaisemmin käytännössä ollut NaCL- ja KCL-liuosten käyttö viljan puhdistamisessa torajyvistä $(18,20)$.

Taulukko 6. Torajyvien seulalajittelun tulokset ja 1000 jyvän paino (eri torajyväkannat keskimäărin). Mäăritykset suoritettu tähkistä poimituista torajyvistä.

Tabelle 6. Die Ergebnisse des Siebsortierens von Mutterkörnern und ihr 1 000-Korngewicht (die verschiedenen Mutterkornstämme im Durchschnitt). Die Bestimmungen sind an aus Ähren gepflückten Mutterkörnern ausgefïhrt worden.

\begin{tabular}{|c|c|c|c|c|c|c|c|}
\hline \multirow{2}{*}{$\begin{array}{l}\text { Vuosi } \\
\text { Jahr }\end{array}$} & \multicolumn{5}{|c|}{$\begin{array}{l}\text { Torajyviä }(\%) \text { eri lajitteissa } \\
\text { ner }(\%) \text { in den verschiedenen Fraktionen }\end{array}$} & \multicolumn{2}{|c|}{$\begin{array}{l}1000 \text { toraj. paino } \\
1000 \text {-Mutterkorngewicht }\end{array}$} \\
\hline & $\begin{array}{c}<2.1 \times 6.5 \\
\mathrm{~mm}\end{array}$ & $\begin{array}{c}2.1 \times 6.5 \\
\mathrm{~mm}\end{array}$ & $\begin{array}{c}2.5 \times 7.5 \\
\mathrm{~mm}\end{array}$ & $\begin{array}{c}3.1 \times 9.5 \\
\mathrm{~mm}\end{array}$ & $\begin{array}{c}3.1 \times 9.5< \\
\mathrm{mm}\end{array}$ & g & $\begin{array}{l}\text { Suhdeluku } \\
\text { Verhältnis- } \\
\text { zahl }\end{array}$ \\
\hline 1952 & 15.9 & 19.9 & 32.5 & 22.5 & 9.2 & 50.4 & 100 \\
\hline 1953 & 11.7 & 23.4 & 39.0 & 19.0 & 6.9 & 42.4 & 84 \\
\hline 1954 & 15.2 & 33.1 & 35.5 & 12.9 & 3.3 & 35.4 & 70 \\
\hline 1955 & 6.0 & 14.2 & 39.6 & 30.7 & 9.5 & 58.4 & 116 \\
\hline
\end{tabular}

V. 1951 ei Viikin koetilan ruissadossa Valtion siementarkastuslaitoksessa suoritettujen viljan puhtausmääritysten mukaan esiintynyt ollenkaan torajyviä. Rukiin lajikekokeissa oli tällöin torajyviä kuitenkin jonkin verran. Lajikekokeiden sato puitiin Teijon Iso Paavo -puimakoneella. Triumph-lajittelu poisti n. 92 \% puinnin jälkeen satoon jääneistä torajyvistä, ja sato (taulukko 7; edessä) saatiin siten sangen puhtaaksi (torajyviä $0.05 \%$ ).

Sen jälkeen kun Viikissä v. 1952 alettiin suorittaa torajyvän viljelykokeita, torajyviä ilmaantui rukiin talousviljelmien satoon. Valtion siementarkastuslaitoksen suorittamien tutkimusten mukaan oli Viikin koetilan talousviljelmien puidussa ja sen jälkeen Petkus-lajittelijalla lajitellussa ruissadossa vv. 1952-1955 ruiskiloa kohden 2-7 torajyvää. Eräässä talousviljelmässä, joka sijaitsi torajyväkokeen välittömässä läheisyydessä (1-86 m:n päässä siitä), torajyviä esiintyi v. 1954 varsin runsaasti (taulukko 7). Sato puitiin Massey Harris -leikkuupuimurilla. Puinnin jälkeen satoon jääneistä torajyvistä saatiin Triumph-lajittelussa poistetuksi n. $95 \%$. Kuitenkin satoon jäi jäljelle torajyviä verraten runsaasti $(0.11 \%$; taulukko 7). 
Taulukko 7. Torajyviä saastuttamattoman Ensi-rukiin jyväsadon eri lajittelufraktioissa vuosina 1952 ja 1954 (Triumph-lajittelija).

Tabelle 7. Mutterkörner in den verschiedenen Sortierungsfraktionen des Kornertrages von nichtinfiziertem Ensi-Roggen in d. J. 1952 und 1954 (Sortierer Triumph).

\begin{tabular}{|c|c|c|c|c|c|c|c|c|c|c|c|c|}
\hline \multirow{6}{*}{$\begin{array}{l}\text { Vuosi } \\
\text { Jahr }\end{array}$} & \multicolumn{12}{|c|}{ Lajittelukoneen } \\
\hline & \multicolumn{3}{|c|}{ edessä } & \multirow{2}{*}{\multicolumn{3}{|c|}{$\begin{array}{l}\text { sivulla } \\
\text { seitlich }\end{array}$}} & \multicolumn{3}{|c|}{ alla } & \multicolumn{3}{|c|}{ takana } \\
\hline & \multicolumn{3}{|c|}{ Vor } & & & & \multicolumn{3}{|c|}{ unter } & \multicolumn{3}{|c|}{ hinter } \\
\hline & \multicolumn{12}{|c|}{ der Sortiermaschine } \\
\hline & \multicolumn{3}{|c|}{$\begin{array}{c}\text { toraj./kg ruista } \\
\text { Mutterk./kg Roggen }\end{array}$} & \multicolumn{3}{|c|}{$\begin{array}{c}\text { toraj./kg ruista } \\
\text { Mutterk./kg Roggen }\end{array}$} & \multicolumn{3}{|c|}{$\begin{array}{c}\text { toraj./kg ruista } \\
\text { Mutterk./kg Roggen }\end{array}$} & \multicolumn{3}{|c|}{$\begin{array}{c}\text { toraj./kg ruista } \\
\text { Mutterk./kg Roggen }\end{array}$} \\
\hline & kpl & g & $\%$ & kpl & g & $\%$ & kpl & g & $\%$ & kpl & $\mathrm{g}$ & $\%$ \\
\hline $\left.1952^{1}\right)$ & 20 & 0.45 & 0.05 & - & - & - & 144 & 1.31 & 0.13 & 457 & 4.20 & 0.42 \\
\hline 1954 & 54 & 1.13 & 0.11 & 177 & 6.62 & 0.66 & 179 & 2.70 & 0.27 & 1000 & 13.10 & 1.31 \\
\hline
\end{tabular}

1) Ruis v:n 1951 satoa. - Roggen der Ernte 1951.

Kokonaisuudessaan on Viikin koetilan ruissato kuitenkin jatkuvasti saatu pidetyksi varsin puhtaana, kuten puidun ja lajitellun vuosina 1952-1955 viljellyn Ensi-rukiin analysointitulokset osoittavat:

Vuosi Viljan käsittely

Jahr Getreidebehandlung

\begin{tabular}{lll}
1952 & \multicolumn{2}{l}{ Lajittelematon } \\
& Unsortiert \\
Lajiteltu & (Petkus) \\
& Sortiert & \\
" & $"$ & (Triumph) \\
1953 & $"$ & (Petkus) \\
1954 & $"$ & $"$ \\
1955 & $"$ & $"$
\end{tabular}

\section{Torajyviä}

Mutterkörner

$\mathrm{g} / \mathrm{kg}$ ruista Roggen

$$
0.163 \pm 0.034
$$

$$
0.178 \pm 0.026
$$

$$
0.153 \pm 0.037
$$

$0.093 \pm 0.035$

0.01

$0.117 \pm 0.032$

0.01

$0.027 \pm 0.007$

0.00

Toisaalta kuitenkin näyttää siltä, ettei perusteellisellakaan lajittelulla voida kokonaan estää ulkomaisen, myrkyllisen torajyväsienikannan leviämistä torajyväviljelmistä ruisviljelmiimme ainakaan siinä tapauksessa, että torajyvä- ja rukiin talousviljelmät ovat lähellä toisiaan.

\section{$P$ ä $\operatorname{a}$ e $l m i \ddot{a}$}

Torajyväsienen, Claviceps purpurea (Fr.) Tul.:n, leviäminen saastutetuista ruiskasvustoista niiden välittömässä läheisyydessä olleisiin ruisviljelmiin oli voimakkainta siellä, missä saastutetut kasvit ulottuivat koskettamaan viljelmän kasvus- 
toa. Jo 1-10 m:n etäisyydellä saastutetusta alasta torajyviä muodostui huomattavasti vähemmän. Kun etäisyys oli vieläkin suurempi, väheni torajyväsaastunta, mutta oli kuitenkin runsaampaa ruisviljelmän reuna- kuin keskiosissa.

Torajyvien luku saastunutta tähkää kohden oli kolmessa tutkitussa torajyväviljelmässä keskimäärin $4.9,5.0$ ja $5.9 \mathrm{kpl}$. Saastutetun alueen ulkopuolella, rukiin talousviljelmissä, vastaavat luvut olivat $1.3,1.6$ ja $2.0 \mathrm{kpl}$. Torajyviä oli saastunutta tähkää kohden vähän enemmän ruisviljelmän reuna- kuin keskiosissa. Sen sijaan ei torajyvien luku ollut sanottavasti riippuvainen siitä, kuinka kaukana kasvi oli saastutetusta rukiista.

Vuosina 1953-1955 keinotekoinen torajyväsaastutus alensi Ensi-rukiin jyväsatoa $23-77 \%$. Sadon aleneminen johtui paitsi jyväluvun ilmeisestä pienentymisestä, myös siitä, että saastuneiden tähkien jyvät olivat terveiden tähkien jyviä kevyempiä; v. 1952 erotus oli $17.6 \%$. Rukiin jyväsatoa alensi lisäksi se, että saastutuksen yhteydessä tapahtui tähkien ja korsien vioittumista.

Saastutetun rukiin jyväsadon orastumiseen torajyväsienellä ei ollut selvää vaikutusta.

Rukiin tavanomaisella puinnilla ja lajittelulla torajyviä ei täydellisesti voitu poistaa viljasta, mutta vilja voitiin puhdistaa siinä määrin, että se täytti kauppakelpoisuusvaatimuksen.

(1) Ано, E. 1953. Torajyvän viljelemisestä Suomessa. Farm. aikak. 5: 115-129.

(2) ANerud, K. 1939. Mjöldryga och ergotism. Landtm. 23: 1185-1188.

(3) BARger, G. 1931. Ergot and ergotism. $279 \mathrm{~s}$. London-Edinburgh.

(4) BÉKÉSY, N. von 1938. Ủber parasitische Mutterkornkulturversuche. Zbl. Bakt. Parasitenk. 99: $321-332$.

(5) — 1940. Untersuchungen über den Alkaloidgehalt des Mutterkornes. II Mitteilung. Uber den Alkaloidgehalt des parasitisch kultivierten Mutterkornes. Biochem. Z. 103: 368 -382.

(6) Bonnier, G. \& Tedin, O. 1940. Biologisk variationsanalys. $325 \mathrm{~s}$. Stockholm.

(7) Dixon, S. 1932. The relation of food to disease. J. Soc. Chem. Ind. 51: 787-795, 808-813.

(8) Guggisberg, H. 1954. Mutterkorn vom Gift zum Heilstoff. $343 \mathrm{~s}$. Basel.

(9) GäUmann, E. 1951. Pflanzliche Infektionslehre. 681 s. Basel.

(10) Неснт, W. 1953. Zur Frage der Ausbreitung von Mutterkorninfektionen. Bodenk. 7: 363-371.

(11) Неске, L. 1921. Die Kultur des Mutterkorns. Schw. Apoth. Ztg. 59: 277-281, 293-296.

(12) Кіrснноғғ, Н. 1929. Beiträge zur Biologie und Physiologie des Mutterkornpilzes. Zbl. Bakt. Parasitenk. 77: $310-369$.

(13) Krebs, J. 1936. Untersuchungen über den Pilz des Mutterkorns Claviceps purpurea Tul. Ber. Schw. Bot. Ges. 45: 71-165.

(14) Kuukausikatsaus Suomen sääoloihin. Ilmat. keskusl. vuosik. 46-49.

(15) LEwis, R. W. 1945. The field inoculation of rye with Claviceps purpurea. Phytop. 35: 353-360.

(16) Mothes, K. \& Silber, A. 1952. Úber den natürlichen Befall der Roggenfelder durch Mutterkorn. Pharmazie 7: $310-313$.

(17) Mǘhle, E. 1953. Vom Mutterkorn. Heft 103: 1-32.

(18) NoввE, F. 1904. Ueber Alexander Müller's Verfahren zur Reinigung des Saatroggens von Mutterkorn durch Sedimentation. Landw. Vers. Stat. 60: 315-319.

(19) RUокоцA, A-L. 1956. Torajyvän viljelykokeista Viikin koetilalla ja eräillä kasvinviljelyskoeasemilla Suomessa. Maatal.tiet. aikak. 28: 203-222. 
(20) Spoof, A. R. 1872. Om förgiftningar med secale cornutum, förnämligast med hensyn till Dragsjukan i Finland. 67 s. Helsingfors.

(21) Stoll, A. 1943. Altes und Neues über Mutterkorn. Mitt. Naturf. Ges. Bern 1942: 45-80.

(22) StÄger, R. 1910. Neue Beobachtungen über das Mutterkorn. Zbl. Bakt. Parasitenk. $27: 67-73$.

(23) Veijola, T. 1954. Vuoden 1953 viljasadon laatu. Maas. Tul. 38,1: 2.

(24) Vladimirsky, S. V. 1939. Geographical distribution and zones of injurious influence of ergot on rye in the U.S.S.R. Sovetsk Bot. 5: 77-87.

(25) Wăhlın, A. M. 1771. Afhandling om den i Småland gångbara Dragsjukan. Kongl. vet. acad. handl. $32: 14-41,153-167$.

R E F E R A T:

\section{UBER AUSBREITUNG UND BEKÄMPFUNG DES MUTTERKORNPILZES, CLAVICEPS PURPUREA (FR.) TUL.}

AnNa-Liss Ruokola

Pflanzenpathologisches Institut der Universität Helsinki

Die Ausbreitung des Mutterkornpilzes, Claviceps purpurea (Fr.) Tul., aus infizierten Roggenbeständen in die in deren unmittelbarer Nähe gelegenen Roggenkulturen war da am stärksten (29-42 $\left.\mathrm{St} . / \mathrm{m}^{2}\right)$, wo die infizierten Pflanzen so weit reichten, dass sie den Bestand der Kultur berührten. Schon in 1-10 m Entfernung von der infizierten Fläche bildeten sich bedeutend weniger Mutterkörner (Tabelle 1). War die Entfernung noch grösser, so verminderte sich der Mutterkornbefall, war aber in den randlichen Teilen der Roggenkultur noch reichlicher als in ihren mittleren Teilen.

Die Anzahl der Mutterkörner je befallene Ähre belief sich bei drei untersuchten Mutterkornkulturen im Mittel auf. 5.3 St. Ausserhalb des infizierten Gebietes, in Wirtschaftskulturen von Roggen, war der entsprechende Betrag 1.6 St. (Tabelle 2). Mutterkörner gab es je infizierte Ähre etwas mehr in den randlichen als in den mittleren Teilen der Roggenkultur. Dagegen war die Anzahl der Mutterkörner nicht nennenswert davon abhängig, in welcher Entfernung vom infizierten Roggen die Pflanze wuchs.

In den Jahren 1953-1955 verminderte eine künstliche Mutterkorninfektion den Kornertrag des Roggens Ensi auf 23-77\% (Tabelle 5). Die Herabsetzung des Ertrages beruhte nicht allein auf der offensichtlichen Verringerung der Körnerzahl, sondern auch darauf, dass die Körner der infizierten Ähren leichter als die der gesunden Ähren waren (Tabelle 3); im J. 1952 betrug der Unterschied $17.6 \%$. Der Kornertrag des Roggens wurde auch dadurch vermindert, dass im Zusammenhang mit der Infektion ein Beschădigen von Ähren und Halmen vor sich ging.

Das Aufspriessen des Kornertrages des infizierten Roggens ist durch den Mutterkornpilz nicht deutlich beeinflusst worden (Tabellen 4 und 5).

Bei dem üblichen Dreschen und Sortieren des Roggens konnten die Mutterkörner aus dem Getreide in dem Masse entfernt werden (0.00-0.11\% Mutterkörner), dass es der Verkäuflichkeitsforderung $(0.25 \%)$ entsprach. Demgegenüber kann aber selbst bei gründlichem Sortieren das Ausbreiten eines ausländischen, giftigen Mutterkornstammes von den Mutterkornkulturen in Roggenkulturen wohl nicht ganz vermieden werden, zum mindesten nicht in dem Falle, dass Mutterkornund Roggen-Wirtschaftskulturen nahe beieinander gelegen sind. 